\title{
Remarks on the Festivities of the Order of the Golden Fleece in Prague (1585)
}

\author{
Jan Bat'a / jan.bata@ff.cuni.cz \\ Ústav hudební vědy, Filozofická fakulta, Univerzita Karlova, Praha, CZ
}

\begin{abstract}
The festivities of the Order of the Golden Fleece in Prague and Landshut in June 1585 have already attracted much attention among historians. This article considers the musical part of the celebration that has yet not been discussed in detail. Using extant narrative, iconographical and musical sources, it focuses on the first part of the festivity which took place at Prague Castle. It postulates a hypothesis that the forty-part motet Ecce beatam lucem from the Mantuan composer and instrumentalist Alessandro Striggio (1536/37-1592) based on the text of German musician and poet Paulus Melissus-Schede (1539-1602) was performed in St. Vitus' cathedral.
\end{abstract}

\section{Key words}

Paulus Melissus (1539-1602), Philippe de Monte (1521-1603), motet, multiple-choir music, Order of the Golden Fleece, Prague, Renaissance festivities, Alessandro Striggio (1536/37-1592), Ratsschulbibliothek Zwickau 
The Order of the Golden Fleece is one of the most renowned chivalric orders. It was founded in 1430 by Phillip the Good, Duke of Burgundy (1397-1467) to cultivate the ideal of Christian chivalry and to maintain the Christian faith. After the extinction of the Burgundian dynasty, the sovereignty of the Order passed to the Habsburg kings of Spain, where it remained until 1700 when the last of the Spanish Habsburgs, Charles II, died. At that time the Order divided into two separate branches - the Spanish and the Austrian that exist until today. ${ }^{1}$

The music activity within the early history of the Order has attracted musicologists since the 1980s. Through the research undertaken mainly by William F. Prizer, Ronald Woodley and Barbara Haggh we are well informed about the musical activities of the Order in Burgundy and the Low Countries. Thanks to them we know how important a role this chivalric and lay religious confraternity played in the music of the $15^{\text {th }}$ and early $16^{\text {th }}$ centuries in the regions mentioned above and how certain pieces of music by first-class composers like Guillaume Dufay (1397-1474), Josquin Desprez (c1450/551521), Nicolas Gombert (c1495-c1560) or Thomas Crecquillon (c1505/15-1557) fit into the spirituality of the Order. ${ }^{2}$ The main focus of this research, however, covers the period before 29 July 1559 when the last Chapter of the Order took place in Ghent. The musical activity within the Order after 1559 thus remains largely unexplored.

The Order of the Golden Fleece also had a close relationship to the Bohemian lands since among the Order's members a number of eminent personalities from the Bohemian kingdom can be found. Therefore, historians have paid much attention to this subject within the past decades. ${ }^{3}$ Not so our historical musicology. Though not completely silent, music historians have published no more than a handful of iconographical documents

1 I am grateful to Gregor Hermann (Ratsschulbibliothek Zwickau) and Petra Hofbauerová (National Library of the Czech Republic) for their kind assistance. The history of the Order and as well as its cultural heritage is discussed in large corpus of literature, e.g. La Toison d'Or: cinq siècles d'art et d'histoire: exposition ... au ... 14. juillet30. septembre 1962: catalogue. Bruges: Administration Communale de Bruges, 1962; Trésors de la Toison d'Or: Europalia 87 Österreich: [Palais des Beaux-Arts, Bruxelles, 16 septembre / 16 décembre 1987]. Bruxelles: Crédit Communal, 1987; HOUART, Pierre - BENOÎT-JEANNIN, Maxime. Histoire de la toison d'or: la prodigieuse aventure d'un ordre éblouissant de Philippe le Bon à nos jours. Bruxelles: Cri, 2006; AUER, Leopold et al. (eds.). Das Haus Österreich und der Orden vom Goldenen Vlies: Beiträge zum wissenschaftlichen Symposium am 30. November und 1. Dezember 2006 in Stift Heiligenkreuz. Graz: Leopold Stocker, 2007.

2 Cfr. PRIZER, William F. Music and Ceremonial in the Low Countries: Philip the Fair and the Order of the Golden Fleece. Early Music History, 1985, Vol. 5, pp. 113-153; WOODLEY, Ronald. Tinctoris's Italian Translation of the Golden Fleece Statutes: A Text and a (Possible) Context. Early Music History, 1988, Vol. 8, pp. 173244; HAGGH, Barbara Helen. The Archives of the Order of the Golden Fleece and Music. Journal of the Royal Musical Association, 1995, Vol. 120, pp. 1-43; Idem. The Order of the Golden Fleece. Journal of the Royal Musical Association, 1996, Vol. 121, pp. 268-270; PRIZER, William F. Charles V, Philip II, and the Order of the Golden Fleece. In Essays on Music and Culture in Honor of Herbert Kellman. Barbara Helen Haggh (ed.). Paris: Minerve, 2001, pp. 161-188; Idem. Brussels and the Ceremonies of the Order of the Golden Fleece. Revue belge de musicologie, 2001, Vol. 55, pp. 69-90; HAGGH, Barbara Helen. The Mystic Lamb and the Golden Fleece: Impressions of the Ghent Altarpiece on Burgundian Music and Culture. Revue belge de musicologie, 2007, Vol. 61, pp. 5-59.

3 Cfr. SEMRÁD, Otto. Zlaté rouno v evropských zemích. Heraldická ročenka, 1990, Vol. 17, pp. 5-20; LOBKOWICZ, František. Zlaté rouno v českých zemích. Heraldika a genealogie, 1991, Vol. 24, pp. 181-280; POKORNÝ, Pavel R. Zlaté rouno Viléma z Rožmberka. In Život na dvoře a v rezidenčních městech posledních Rožmberků. České Budějovice 1993, pp. 401-403; SEMRÁD, Otto. Zlaté rouno v evropských zemích. Heraldika a genealogie, 2002, Vol. 35, pp. 49-64; POKORNÝ, Pavel R. Zlaté rouno a Čechy. Heraldická ročenka, 2013, Vol. 37, pp. 124-126. 
related to the Prague ceremony of 1585 which will be now discussed in greater detail. ${ }^{4}$

The celebration of the Order of the Golden Fleece held in Prague on $2^{\text {nd }}$ and $3^{\text {rd }}$ June 1585 deserves our closer attention because it was one of the greatest festivities in the capital of the Bohemian kingdom at the end of the $16^{\text {th }}$ century. During the ceremony, Emperor Rudolf II (1552-1612) became a member of the Order together with his brother Ernst (1553-1595) and his uncle Karl II, Duke of Styria (1540-1590). Among the newly received knights of the Order there were also two members of high Bohemian nobility - William of Rosenberg (1535-1592) and Leonhard of Harrach (1514-1590). A detailed printed description of the festivities, published in 1587 by Paul Zehendtner vom Zehendtgrub, the secretary to the Archduke Ferdinand of Tirol, has been preserved. ${ }^{5}$ Apart from the narrative sources, a rich iconographical testimony, made by the painter Anthoni Bays (1543-1615), has survived. ${ }^{6}$ His pictures also accompany Zehendtner's book. Some of these images were hitherto neglected by music historians (see fig. 1, 2 \& 3). ${ }^{7}$ Zehendtner's original text is familiar to scholars not only through easily accessible digital facsimile but also through extensive commentaries in the relevant literature. ${ }^{8}$

4 Cfr. JAREŠ, Stanislav - KOUBA, Jan. Z hudebního života pražského dvora před třicetiletou válkou. Hudebni věda, 1972, Vol. 9, pp. 69-73; VOLEK, Tomislav -JAREŠ, Stanislav (eds). Dějiny české hudby v obrazech: od nejstaršich památek do vybudování Národního divadla. Praha: Editio Supraphon, 1977, illustration nr. 117.

5 ZEHENDTNER VOM ZEHENDTGRUB, Paul. Ordentliche Beschereibung mit was stattlichen Ceremonien und Zierlichheiten, die Röm [ische] Kay[ serliche] May[estät], unser aller gnedigster Herr, sampt etlich andern Ertzherzogen, Fürsten und Herrn den Ordens deß Guldin Flüß in di [e] sem 85. Jahrzu Prag und Landshut empfangen und angenommen [...] . Dilingen: Johann Mayer, 1587 (VD 16 Z 225).

6 Wien, Kunsthistorische Museum, Sammlung für Plastik und Kunstgewerbe, Inv. No. P 5348; Wien, Österreichische Nationalbibliothek, Cod. 7906 Han. Cfr. FUČÍIKOVÁ, Eliška et al. (ed.). Rudolf II. a Praha: císařský dvưr a rezidenčni město jako kulturní a duchovni centrum střední Evropy: katalog vystavených exponáti̊: [Praha 30. května - 7. zář́ 1997]. Praha: Správa Pražského hradu, 1997, p. 226; SEIPEL, Wilfried (ed.). Wir sind Helden: Habsburgi sche Feste in der Renaissance. Wien: Kunsthistorisches Museum, 2005, pp. 20-22.

7 For the relationship of Anthoni Bays and the Bohemian Lands cfr. KŘížOVÁ, Květa. Anthoni Bays a jeho dílo v Čechách. Umění, 1981, Vol. 29, pp. 347-359, esp. pp. 354-355.

8 Cfr. JANÁČEK, Josef. RudolfII. a jeho doba. Praha: Svoboda, 1987, pp. 255-268; KÖRNDLE, Franz. Orlando di Lasso's 'Firewors' Music. Early Music, 2004, Vol. 32, pp. 96-116, esp. pp. 100-101; BŮŽEK, Václav. Ferdinand Tyrolský mezi Prahou a Innsbruckem: šlechta z českých zemi na cestě ke dvori̊m proních Habsburkü. České Budějovice: Historický ústav Filozofické fakulty Jihočeské univerzity, 2006, pp. 238-250; German version cfr. Idem. Ferdinand von Tirol zwischen Prag und Innsbruck: der Adel aus den böhmischen Ländern auf dem Weg zu den Höfen der ersten Habsburger. Wien: Böhlau, 2009, pp. 285-300. 


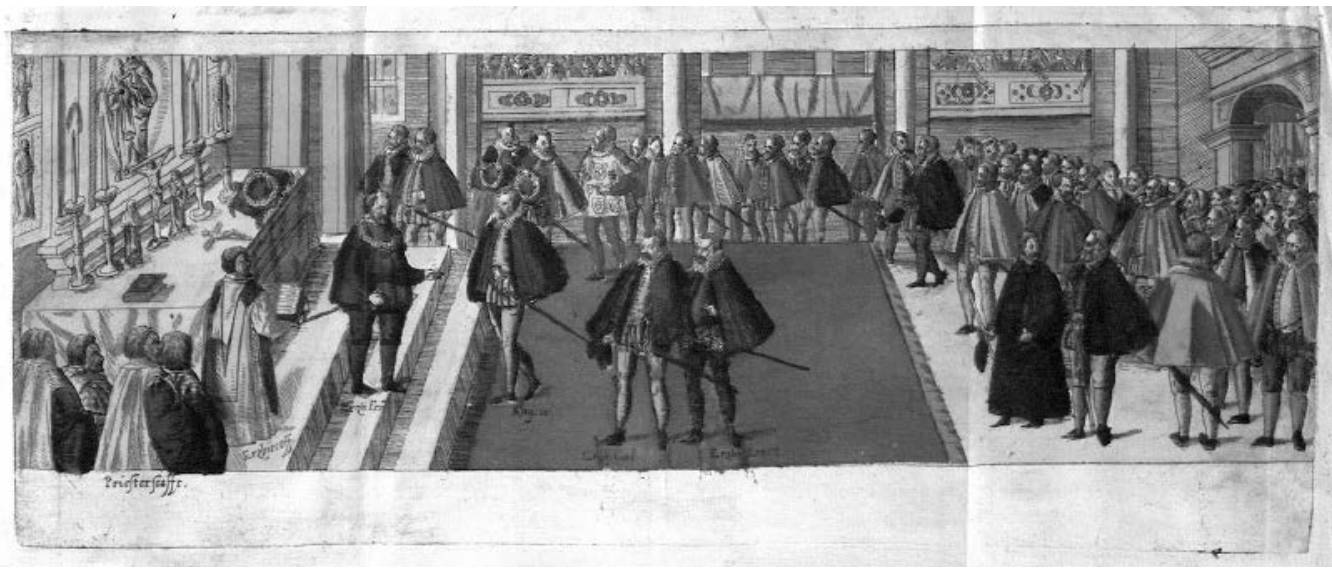

Fig. 1. Anthoni Bays: The celebration of the Order of the Golden Fleece. St. Vitus' cathedral (trumpeters are standing at the upper right balcony). Source: ZEHENDTNER VOM ZEHENDTGRUB, Paul. Ordentliche Beschereibung, illustration between pp. 104 and 105 (@National Library of the Czech Republic. Published with permission.)

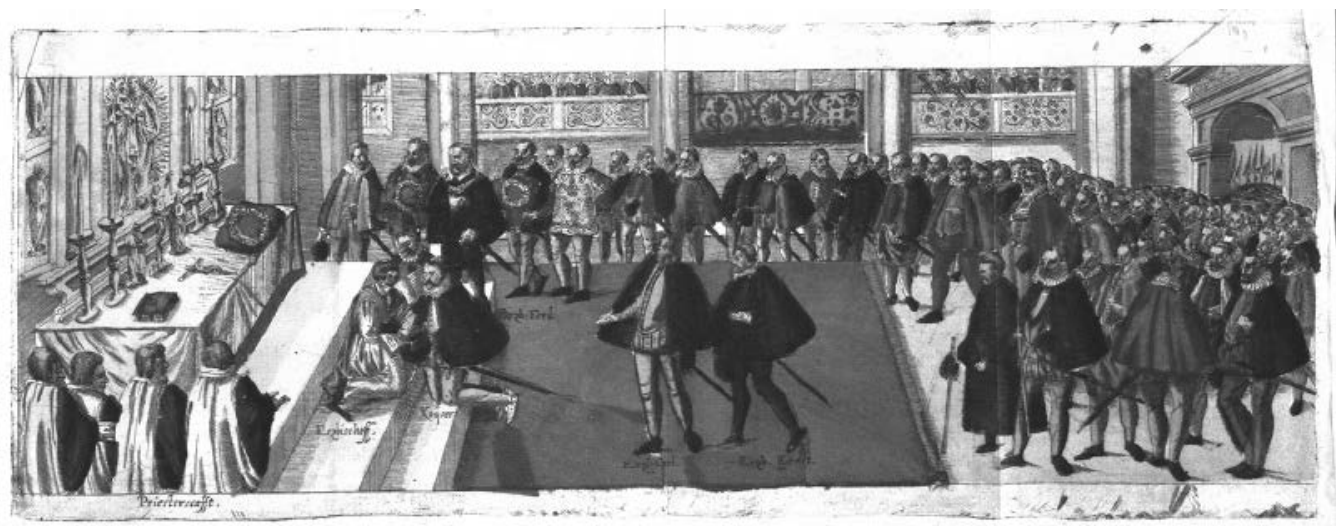

Fig. 2. Anthoni Bays: The celebration of the Order of the Golden Fleece. St. Vitus' cathedral (trumpeters and singers (?) are standing at the upper right balcony). Source: ZEHENDTNER VOM ZEHENDTGRUB, Paul. Ordentliche Beschereibung, illustration between pp. 106 and 107 (@National Library of the Czech Republic. Published with permission.)

The main part of the ceremony took place in St. Vitus' Cathedral during a solemn mass. Paul Zehendtner explicity mentions music performance several times. Firstly, at the moment when the solemn procession entering the cathedral was welcomed by the Imperial trumpeters and drummers. ${ }^{9}$ In addition, their participation is recorded during the main

9 ZEHENDTNER VOM ZEHENDTGRUB, Paul. Ordentliche Beschereibung, p. 101: „Wie mann nun also in die 


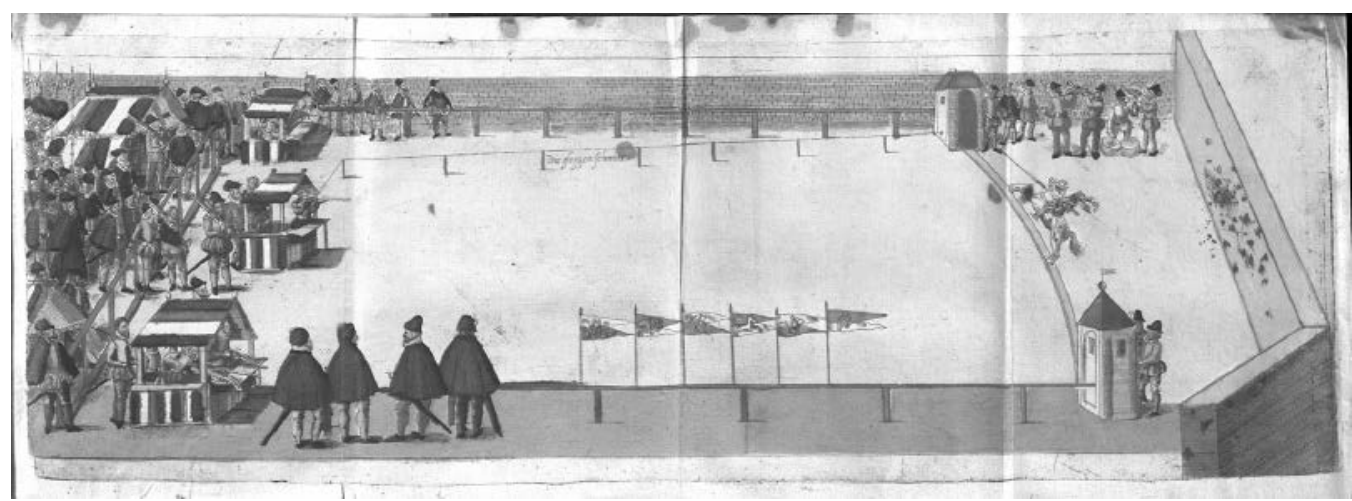

Fig. 3. Anthoni Bays: The celebration of the Order of the Golden Fleece. Shooting tournament (trumpeters and drummer are standing it the upper right corner). Source: ZEHENDTNER VOM ZEHENDTGRUB, Paul. Ordentliche Beschereibung, illustration between pp. 130 and 131 (@National Library of the Czech Republic. Published with permission.)

act of the decoration. ${ }^{10}$ The most important reference is also the most enigmatic: during the offertory there was performed excellent and beautiful music for four different choirs, two standing in the lateral naves while the other two next to the organ. ${ }^{11}$

One question arises: which composition could have sounded through St. Vitus' Cathedral? Michael Silies in his monograph on the motets of the Rudolfine chapel master Philippe de Monte (1521-1603), thinks that the three-choir motet Benedictio et claritas for twelve voices was performed during this occasion. His argumentation is very careful, yet the result is plausible. Monte sets the text drawing upon the seventh chapter the Revelation of St. John - "Benedictio, et claritas, et sapientia, et gratiarum actio, honor, virtus, et fortitudo Deo nostro in saecula saeculorum. Amen." [Blessing and glory, wisdom and thanksgiving, honour, power, and might be to our God forever and ever. Amen.] $]^{12}$ This text can have several connections to the Prague celebration of the Order of the Golden Fleece: 1) it is the antiphon taken from the feast of the Holy Trinity that was close to this festivity at that time, 2) the original text is an exclamation four angels from the four

Haupt Kirch deß Schloß kommen / darinnen dann der Chor schon darvor zu disem Herrlichen Actu von Prettern was erhoecht / und mit koestlichen guldinen Tapezereyen / auch sonst aller notturfft nach herrlich und stattlich zuegericht unnd geziert gewesen / haben alß bald die ob der Porkiche neben der grossen Orgl / verordnete Kayserliche Hoerpaugger und Trummetter / sich zu ihr er Kay [ serliche] $M[$ ayestä] t und der andern Ertzhertzogen unnd Fürsten eingang hoeren lassen. [...]“

10 Ibidem, p. 108.

11 Ibidem, p. 111-112: „Neben demselben man eben in der Ordnung / wie man in die Kirchen kommen / vom Altar hinbauff in ihr Kay[ serliche] May[estät] Oratorium gangen / sich derauff das Ampt / || welliches durch mehrberuehrte ihr

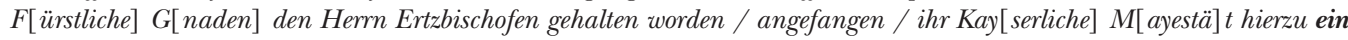
treffenliche schoene Music von vier underschidlichen Chorn / deren die zwen herunden bey der Cappellen / die zwen andere aber auff der Porkirchen / bey der Orgel / fast lieblich und künstlich zuhoern gewesen. [...]“ (bold type by J. B.) 12 Apc. 7, 12. 
different corners of the earth, 3) the printed collection that contains this motet was published in 1585 and was dedicated to Adam of Dietrichstein (1527-1590), a tutor of young princes Rudolf and Ernst. ${ }^{13}$ The only argument against this hypothesis is that the piece is composed for three, not for four choirs. Nevertheless, Philippe de Monte, in his letter written on 10 June 1588, mentioned a mass for three choirs performed during the Prague celebration of the Order of the Golden Fleece in 1585 that could not have been sung and played with the great organ of St. Vitus' Cathedral because of bad pitch. ${ }^{14}$ Thus we are confronted with confusing testimonies of eyewitnesses recorded in different sources - a mass ordinary for three choirs mentioned in Monte's letter against an offertory motet (?) for four choirs reported in Zehendtner's description.

However, it must have been something extraordinary when Paul Zehendtner explicitly mentioned four choirs in his text that otherwise does not pay much attention to the music. Therefore, I would like to present another hypothesis and to suggest what kind of composition could have sounded in St. Vitus' Cathedral during the offertory. In the Rathsschulbibliothek in Zwickau (Saxony), there has been preserved a unique manuscript of the motet Ecce beatam lucem for forty voices written by the Mantuan composer and instrumentalist Alessandro Striggio (1536/37-1592) who was also engaged in the diplomatic service of the Medici family. ${ }^{15}$ The manuscript, whose original provenance is unknown, is written on forty-one separate sheets of paper and seems to be adapted for actual performance. ${ }^{16}$ The basso seguente part bears a chronogram 1587 which is in accordance with the dating of the watermark that locates the origins of the paper to Dresden. ${ }^{17}$ However, several corrected mistakes prove that the manuscript we are now facing, is a copy of an earlier original. I shall give at least two examples. On sheet $1^{\mathrm{e}}$ at

13 Cfr. SILIES, Michael. Die Motetten des Philippe de Monte (1521-1603). Göttingen: V\&R Unipress, 2009, pp. 247-250. See also SANDBICHLER, Veronika. Elements of Power in Court Festivals of Habsburg Emperors. In Ceremonial Entries in Early Modern Europe: The Iconography of Power. J. R. Mulryne - Maria Ines Aliverti - Anna Maria Testavede (eds.). Farnham: Ashgate, 2015, pp. 167-187, esp. pp. 182-183. The critical approach to the hypothesis of Michael Silies can be found in HONISCH, Erika Supria. Sacred Music in Prague, $1580-1612$. Ph.D. dissertation, University of Chicago, 2011, p. 171.

14 Cfr. KÖPL, Karl. Urkunden, Acten und Regesten aus dem K. K. Statthalterei-Archiv in Prag. Jahrbuch der Kunsthistorischen Sammlungen des Allerhöchsten Kaiserhauses, 1891, Vol. 12, p. LXXV: „Erstlich ist die orgel von dem gewönlichen ton umb ein semitonium oder halbe stimb verruckht, welches der capelln ein grosse ungelegenheit gibt dermassen, das si zu Zeiten anstat singens schreien muss. Daher den auch erfolgt, dass, wenn man hat wollen etwas zusamen stimen, wie nechstermals geschechen, als ier kais. maj. das gülden flüss empfangen, da eine mess von drei choren gesungen und allerlai instrument darein gangen, gemelte orgel darumben, das si umb ein halbe stimb zu hoch, nit gebraucht werden mögen sunder man sich ier kais. maj. regals mit grosser ungelegenhait behelfen müessen." Cited also by SILIES, Michael. Die Motetten, p. 249, but with confusing reference. Cfr. also QUOIKA, Rudolf. Die Prager Kaiserorgel. Kirchenmusikalisches Jahrbuch, 1952, Vol. 36, 1952, pp. 35-46; PRUETT, Lilian P. An Organ Building Project of the Sixteenth Century: The Large Organ of St. Vitus Cathedral in Prague. In Music in the Theater, Church and Villa: Essays in Honor of Robert Lamar Weaver and Norma Wright Weaver. Susan Helen Parisi - Ernest Charles Harriss - Calvin M. Bower (eds.). Warren: Harmonie Park Press, 2000, pp. 81-88.

15 Zwickau, Rathsschulbibliothek, Mus. 109.1 $1^{\text {a-oo }}$. The critical edition see in STRIGGIO, Alessandro - KEYTE, Hugh (ed.). Ecce Beatam Lucem: For 40 Voices. London: Mapa Mundi, 1980.

16 There has been added basso seguente as the $41^{\text {st }}$ voice.

17 BRIQUET, Charles M. Les Filigranes: dictionaire historique des marques du papier. 3. Nachdruckauflage der Ausgabe Leipzig. Vol. 1, Hildesheim: Olms, 1991, Nr. 1416: Dresden 1583, var. simil. Dresden 1584-1592, Görlitz 1586-1590, Köppenigh 1587, Halle 1589-1590. 
the end of the second line, the scribe copied music from two earlier phrases. He then realized his mistake and crossed it out. On sheet $1^{\mathrm{v}}$ at the end of the first line, the scribe omitted one phrase which he had to copy down in margine. Such mistakes and omissions are not unusual in this source. The fact that the piece has come down to us a single copy is also not surprising. We know that Striggio had to compose the motet in 1561 at latest, because in that year it was performed for the first time in both Florence and Mantua. ${ }^{18}$ Another opportunity came seven years later during the splendid wedding of the Bavarian Duke Wilhelm V (1548-1626) and Renata of Lorraine (1544-1602) in Munich. ${ }^{19}$ The forty-part motet Ecce beatam lucem is not the sole composition Striggio's for multiple choirs. He also wrote a parody mass for forty voices which was rediscovered by Davitt Moroney in the Bibliothčque nationale de France in Paris and that is derived from the motet, though it bears a different title: Ecco si beato giorno. ${ }^{20}$

Apart from other connotations, this mass has a strong connection to the Habsburg court. In the winter of 1566, Striggio undertook the very dangerous journey across the Alps to present the composition to the Emperor Maximilian (1527-1576) in Vienna in order to convince him to grant Striggio's patron Francesco de Medici (1541-1587) the title of Grand Duke of Tuscany. Striggio started his journey on $5^{\text {th }}$ December 1566 in Mantua, crossed the Alps and went through Innsbruck, Hall, Salzburg, Linz and St. Pölten to Vienna where he arrived on 31 December. Unfortunately, he missed the Emperor who had left the previous day for Brno. Striggio thus moved from Vienna to Brno where he finally presented his forty-part mass to Maximilian who, however did not have enough musicians with him to perform it. Therefore, this diplomatic mission was not as successful as Francesco de Medici and Alessandro Striggio had hoped. ${ }^{21}$ Even so the motet is linked with the Habsburgs because it was performed in 1561 during the wedding of Maximilian's sister Eleonora (1534-1594) to Guglielmo Gonzaga (1538-1587). ${ }^{22}$ We can therefore assume that the knowledge of the existence of these two exceptional pieces of music entered into the milieu of the Imperial court.

If we want to identify Striggio's motet Ecce beatam lucem with the four-choir composition performed during the ceremony of the Order of the Golden Fleece in Prague in June 1585, it is necessary to support this hypothesis by stronger arguments than a supposed familiarity of the Habsburg court with Striggio's multiple-choir music. One of the

18 Cfr. FENLON, Iain - KEYTE, Hugh. Memorialls of Great Skill: A Tale of Five Cities. Early Music, 1980, Vol. 8, pp. 329-331, 333-334, esp. pp. 333-334.

19 Cfr. LEUCHTMANN, Horst (ed.) Die Münchner Fürstenhochzeit von 1568: Massimo Troiano: Dialoge italienisch/deutsch. München: Emil Katzbichler, 1980, p. 308.

20 Cfr. MORONEY, Davitt. Alessandro Striggio's Mass in Forty and Sixty Parts. Journal of the American Musicological Society, 2007, Vol. 60, pp. 1-70. Moroney speculates that the motet could exist even with the Italian text and that this version became a model for the previously mentioned mass.

21 For detailed description of Striggio's journey cfr. BUTCHART, David S. A Musical Journey of 1567: Alessandro Striggio in Vienna, Munich, Paris and London. Music $\mathcal{E}$ Letters, 1982, Vol. 63, pp. 1-16. See also Idem. The Letters of Alessandro Striggio: An Edition with Translation and Commentary. Royal Musical Association Research Chronicle, 1990, Vol. 23, pp. 1-78, esp. pp. 22-24.

22 FENLON, Iain - KEYTE, Hugh. Memorialls of Great Skill, p. 333; BUTCHART, David S. The Letters of Alessandro Striggio, pp. 13-15. 
arguments is the division of the choirs. The original music is written for five eight-part choirs but the Zwickau manuscript divides the music only into four unequal choirs for eight, ten, sixteen and six voices. ${ }^{23}$ The distribution of choirs - though curious - coincides with the description of Paul Zehendtner who says there were four different choirs. ${ }^{24}$

Another clue for the identification of Ecce beatam lucem with the four-choir composition performed during the mass of the Order of the Golden Fleece at St. Vitus' Cathedral is the text of the motet whose author is German musician and poet Paulus Melissus-Schede (1539-1602). He studied in Zwickau, Erfurt and Jena. He then worked at several locations in Central Europe including Vienna, Wittemberg and Leipzig. He also travelled extensively to France, Italy and England and eventually died in Heidelberg. ${ }^{25}$ Melissus was in close contact with Bohemian humanists and with the intellectual circles related to the court of Rudolf II. ${ }^{26}$ The text Ecce beatam lucem is part of the ode entitled Enthusiasticon de nova Hierosolyma which was published in 1595 in Melissus' collection Meletematum piorum libri octo. ${ }^{27}$ The poet created a paraphrase of the last two chapters of the Book of Revelation that describes the apostle's vision of the celestial Jerusalem: ${ }^{28}$

Ecce beatam lucem, ecce bonum sempiternum.

Vos, turba electa, celebrate Jehovam eiusque natum aequalem Patri, Deitatis splendorem.

Virtus alma et maiestas passim cernenda adest.

Quantum decoris illustri in sole,

quam venusta es, luna,

quam multo clara honore sidera fulgent,

quam pulcra quaeque in orbe.

$O$, quam perennis esca

tam sanctas mentes pascit!

Praesto gratia et amor, praesto ver novum;
Behold the blessed light, behold the everlasting goodness. You chosen assembly, praise God and his Son, who equals the Father in the glory of his godhead. Benign power and majesty are to be seen all around. The dazzling splendour of the sun is matched by thee, O comely moon,

and by the stars shining brightly in their great glory; indeed all creation is magnificent.

O how the eternal nourishment

feeds such holy minds!

Here are grace and love as of old,

23 For further comments on the distribution of the choirs see FENLON, Iain - KEYTE, Hugh. Memorialls of Great Skill, pp. 330, 331, 333.

24 See footnote no. 11. This kind of composition needs sufficient performing staff. If we consider the number of Rudolfine musicians at those times and the possible participation of performers from the other Habsburg courts (especially those of Archduke Ferdinand and Carl), there would be enough musicians for the performance.

25 Cfr. FECHNER, Jörg-Ulrich - DEHNHARD, Hans. Melissus, Paulus. In Neue Deutsche Biographie [online]. [cit. 2015-12-11]. Dostupné z: <http:/ / www.deutsche-biographie.de/pnd118580558.html >.

26 Cfr. TRUHLÁ̌̌, Antonín, ed. et al. Rukovět humanistického básnictví v Čechách a na Moravě = Enchiridion renatae poesis Latinae in Bohemia et Moravia cultae. Vol. 3. Praha: Academia, 1969, p. 311; EVANS, Robert John Weston. Rudolf II and his world: a study in intellectual history 1576-1612. [London]: Thames and Hudson, 1997, passim.

27 SCHEDE-MELISSUS, Paulus. Meletematum piorum libri octo [...]. Frankfurt: Hieronymus Commelinus, 1595 (VD 16 S 2413), p. 90.

28 The English translation cited according to FENLON, Iain - KEYTE, Hugh. Memorialls of Great Skill, p. 330 . 
praesto est fons perpes vitae.

Hic Patriarchae cum Prophetis, hic David,

Rex David ille vates,

cantans sonans adhuc aeternum Deum.

$O$, mel et dulce nectar,

o, fortunatam sedem!

Haec voluptas, haec quies, haec meta, hic scopus nos hinc attrahunt recta in paradisum. here is the ever-flowing fount of life.

Here are Patriarchs and Prophets and David the King, the famous Seer, singing and making music to the eternal God.

$O$ honey and sweet nectar,

O blessed place!

This delight, this peace, this goal, this sureness-they draw us hence straight to heaven.

Finally, it is important to ask: how this eschatological vision fits into the spirituality of the Order of the Golden Fleece? We know that its three main pillars were the devotion to St. Andrew, The Blessed Virgin Mary and to the Holy Spirit. ${ }^{29}$ Nevertheless, we also have to keep in mind the sign of the order - the lamb being a symbol of Jesus Christ as well as the eucharist. In this context it is not inappropriate to remember the famous Ghent altarpiece called The Adoration of the Mystic Lamb that - as Barbara Haggh proved some years ago - had a strong influence upon the order's sovereign Phillip the Good and thus became an integral part of the order's spirituality. ${ }^{30}$ The eucharist symbolism, hand in hand with the elite character of the Order that protected the catholic faith, perfectly fits into the ceremony in Prague at the beginning of June 1585 when membership was granted to members of the ruling Habsburg dynasty along with the foremost Catholic nobility of the Bohemian kingdom.

We can conclude that the Prague ceremony of the Order of the Golden Fleece can be understood as one of the very important milestones on the way of the restoration of Catholicism in an otherwise "heretical" country. The motet of Alessandro Striggio Ecce beatam lucem performed in this context would impress the audience not only by its mighty sound but also by its highly symbolic message. The archival support for this hypothesis is, however, scarce. Apart from the Landshut celebration which is very well documented, ${ }^{31}$ for the Prague festivity there exists only indirect evidence which ought to become the subject of further discussion.

\section{Bibliography}

\section{Sources}

SCHEDE-MELISSUS, Paulus. Meletematum piorum libri octo [...]. Frankfurt: Hieronymus Commelinus, 1595 (VD 16 S 2413). Investigated copy: München, Bayerische Staatsbibliothek, Außenmagazin, shelf-mark P.o.lat. 921.

29 PRIZER, William F. Music and Ceremonial, passim.

30 HAGGH, Barbara Helen. The Mystic Lamb. Cfr. also TOVAČOvSKÝ, Jaroslav. Agnus Dei, qui tollis peccata mundi, Miserere nobis. Původní symbolika řádu Zlatého rouna. Heraldická ročenka, 2013, Vol. 37, pp. 82-94.

31 Cfr. KÖRNDLE, Franz. Orlando di Lasso's 'Firewors' Music. 
ZEHENDTNER VOM ZEHENDTGRUB, Paul. Ordentliche Beschereibung mit was stattlichen Ceremonien und Zierlichheiten, die Röm[ische] Kay[serliche] May[estät], unser aller gnedigster Herr, sampt etlich andern Ertzherzogen, Fürsten und Herrn den Ordens deß Guldin Flüß in disem 85. Jahr zu Prag und Landshut empfangen und angenommen [...]. Dilingen: Johann Mayer, 1587 (VD 16 Z 225). Investigated copy: Prague, National Library of the Czech Republic, Manuscripts and Early Printed Books Department, shelf-mark 65 D 3135.

Zwickau, Rathsschulbibliothek, Mus. 109.1 a-oo, STRIGGIO, Alessandro. Ecce beatam lucem, 41vv (Ms.).

\section{Literature}

AUER, Leopold et al. (eds.). Das Haus Österreich und der Orden vom Goldenen Vlies: Beiträge zum wissenschaftlichen Symposium am 30. November und 1. Dezember 2006 in Stift Heiligenkreuz. Graz: Leopold Stocker, 2007.

BRIQUET, Charles M. Les Filigranes: dictionaire historique des marques du papier. 3. Nachdruckauflage der Ausgabe Leipzig. Hildesheim: Olms, 1991. 4 Vols.

BUTCHART, David S. A Musical Journey of 1567: Alessandro Striggio in Vienna, Munich, Paris and London. Music Eं Letters, 1982, Vol. 63, pp. 1-16.

BUTCHART, David S. The Letters of Alessandro Striggio: An Edition with Translation and Commentary. Royal Musical Association Research Chronicle, 1990, Vol. 23, pp. 1-78.

BŮŽEK, Václav. Ferdinand Tyrolský mezi Prahou a Innsbruckem: šlechta z českých zemi na cestě ke dvorům pronich Habsburků. České Budějovice: Historický ústav Filozofické fakulty Jihočeské univerzity, 2006.

BU゚ŽEK, Václav. Ferdinand von Tirol zwischen Prag und Innsbruck: der Adel aus den böhmischen Ländern auf dem Weg zu den Höfen der ersten Habsburger. Wien: Böhlau, 2009.

EVANS, Robert John Weston. Rudolf II and his world: a study in intellectual history 1576-1612. [London]: Thames and Hudson, 1997.

FENLON, Iain - KEYTE, Hugh. Memorialls of Great Skill: A Tale of Five Cities. Early Music, 1980, Vol. 8, pp. 329-331, 333-334.

FUČÍKOVÁ, Eliška et al. (ed.). Rudolf II. a Praha: císařský dvưr a rezidenčni město jako kulturní a duchovni centrum středni Evropy: katalog vystavených exponátů: [Praha 30. května - 7. zář́ 1997]. Praha: Správa Pražského hradu, 1997.

HAGGH, Barbara Helen. The Archives of the Order of the Golden Fleece and Music. Journal of the Royal Musical Association, 1995, Vol. 120, pp. 1-43.

HAGGH, Barbara Helen. The Order of the Golden Fleece. Journal of the Royal Musical Association, 1996, Vol. 121, pp. 268-270.

HAGGH, Barbara Helen. The Mystic Lamb and the Golden Fleece: Impressions of the Ghent Altarpiece on Burgundian Music and Culture. Revue belge de musicologie, 2007, Vol. 61, pp. 5-59.

HONISCH, Erika Supria. Sacred Music in Prague, 1580-1612. Ph.D. dissertation, University of Chicago, 2011.

HOUART, Pierre - BENOÎT-JEANNIN, Maxime. Histoire de la toison d'or: la prodigieuse aventure d'un ordre éblouissant de Philippe Le Bon à nos jours. Bruxelles: Cri, 2006.

JANÁČEK, Josef. Rudolf II. a jeho doba. Praha: Svoboda, 1987.

JAREŠ, Stanislav - KOUBA, Jan. Z hudebního života pražského dvora před třicetiletou válkou. Hudebni věda, 1972, Vol. 9, pp. 69-73. 
KÖPL, Karl. Urkunden, Acten und Regesten aus dem K. K. Statthalterei-Archiv in Prag. Jahrbuch der Kunsthistorischen Sammlungen des Allerhöchsten Kaiserhauses, 1891, Vol. 12, pp. I-XC.

KÖRNDLE, Franz. Orlando di Lasso's 'Firewors' Music. Early Music, 2004, Vol. 32, pp. 96-116.

KŘÍŽOVÁ, Květa. Anthoni Bays a jeho dílo v Čechách. Uměni, 1981, Vol. 29, pp. 347-359.

LEUCHTMANN, Horst (ed.) Die Münchner Fürstenhochzeit von 1568: Massimo Troiano: Dialoge italienisch/deutsch. München: Emil Katzbichler, 1980.

LOBKOWICZ, František. Zlaté rouno v českých zemích. Heraldika a genealogie, 1991, Vol. 24, pp. 181-280.

MORONEY, Davitt. Alessandro Striggio's Mass in Forty and Sixty Parts. Journal of the American Musicological Society, 2007, Vol. 60, pp. 1-70.

POKORNÝ, Pavel R. Zlaté rouno Viléma z Rožmberka. In Život na dvoře a v rezidenčnich městech poslednich Rožmberků. České Budějovice 1993, pp. 401-403.

POKORNÝ, Pavel R. Zlaté rouno a Čechy. Heraldická ročenka, 2013, Vol. 37, pp. 124-126.

PRIZER, William F. Music and Ceremonial in the Low Countries: Philip the Fair and the Order of the Golden Fleece. Early Music History, 1985, Vol. 5, pp. 113-153.

PRIZER, William F. Brussels and the Ceremonies of the Order of the Golden Fleece. Revue belge de musicologie, 2001, Vol. 55, pp. 69-90.

PRIZER, William F. Charles V, Philip II, and the Order of the Golden Fleece. In Essays on Music and Culture in Honor of Herbert Kellman. Barbara Helen Haggh (ed.). Paris: Minerve, 2001, pp. 161-188.

PRUETT, Lilian P. An Organ Building Project of the Sixteenth Century: The Large Organ of St. Vitus Cathedral in Prague. In Music in the Theater, Church and Villa: Essays in Honor of Robert Lamar Weaver and Norma Wright Weaver. Susan Helen Parisi - Ernest Charles Harriss - Calvin M. Bower (eds.). Warren: Harmonie Park Press, 2000, pp. 81-88.

QUOIKA, Rudolf. Die Prager Kaiserorgel. Kirchenmusikalisches Jahrbuch, 1952, Vol. 36, 1952, pp. $35-46$.

SANDBICHLER, Veronika. Elements of Power in Court Festivals of Habsburg Emperors. In Ceremonial Entries in Early Modern Europe: The Iconography of Power. J. R. Mulryne -Maria Ines Aliverti - Anna Maria Testavede (eds.). Farnham: Ashgate, 2015, pp. 167-187.

SEIPEL, Wilfried (ed.). Wir sind Helden: Habsburgische Feste in der Renaissance. Wien: Kunsthistorisches Museum, 2005.

SEMRÁD, Otto. Zlaté rouno v evropských zemích. Heraldická ročenka, 1990, Vol. 17, pp. 5-20.

SEMRÁD, Otto. Zlaté rouno v evropských zemích. Heraldika a genealogie, 2002, Vol. 35, pp. 49-64.

SILIES, Michael. Die Motetten des Philippe de Monte (1521-1603). Göttingen: V\&R Unipress, 2009.

La Toison d'Or: cinq siècles d'art et d'histoire: exposition ... au ... 14. juillet - 30. septembre 1962: catalogue. Bruges: Administration Communale de Bruges, 1962.

TOVAČOVSKÝ, Jaroslav. Agnus Dei, qui tollis peccata mundi, Miserere nobis. Původní symbolika řádu Zlatého rouna. Heraldická ročenka, 2013, Vol. 37, pp. 82-94.

Trésors de la Toison d'Or: Europalia 87 Österreich: [Palais des Beaux-Arts, Bruxelles, 16 septembre / 16 décembre 1987]. Bruxelles: Crédit Communal, 1987.

TRUHLÁŘ, Antonín, ed. et al. Rukovět humanistického básnictvi v Čechách a na Moravě = Enchiridion renatae poesis Latinae in Bohemia et Moravia cultae. Praha: Academia, 1966-2011. 6 Vols.

VOLEK, Tomislav - JAREŠ, Stanislav (eds). Dějiny české hudby v obrazech: od nejstarších památek do vybudování Národního divadla. Praha: Editio Supraphon, 1977.

WOODLEY, Ronald. Tinctoris's Italian Translation of the Golden Fleece Statutes: A Text and a (Possible) Context. Early Music History, 1988, Vol. 8, pp. 173-244. 
